\title{
PENGARUH STRUKTUR MODAL DAN LIKUIDITAS TERHADAP PROFITABILITAS BANK YANG TERDAFTAR DI BURSA EFEK INDONESIA
}

\author{
Kadek Rionita ${ }^{1}$ \\ Nyoman Abundanti ${ }^{2}$ \\ ${ }^{1,2}$ Fakultas Ekonomi dan Bisnis Universitas Udayana (Unud), Bali, Indonesia \\ e-mail : kadekrionita@gmail.com
}

\begin{abstract}
ABSTRAK
Profitabilitas merupakan indikator yang tepat untuk mengukur kinerja suatu bank. Penilaian profitailitas bermanfaat untuk mengetahui kemampuan perusahaan dalam menciptakan keuntungan dari modal yang digunakan. Penelitian ini bertujuan untuk mengetahui pengaruh Struktur Modal dan Likuiditas terhadap profitabilitas perusahaan bank di Bursa Efek Indonesia. Populasi yang digunakan dalam penelitian ini adalah seluruh perusahaan perbankan yang terdaftar di Bursa Efek Indonesia periode 2013-2016. Teknik penentuan sampel yang digunakan adalah purposive sampling, berdasarkan kriteria penentuan sampel maka sampel yang didapat adalah 33 perusahaan perbankan yang terdaftar di Bursa Efek Indonesia periode 2013-2016. Berdasarkan hasil analisis ditemukan bahwa debt ratio berpengaruh negatif signifikan terhadap return on equity perusahaan bank di Bursa Efek Indonesia, debt to equity ratio berpengaruh positif signifikan terhadap return on quity perusahaan Bank di Bursa Efek Indonesia, loan to deposit ratio berpengaruh positif signifikan terhadap Return On Equity perusahaan bank di Bursa Efek Indonesia.
\end{abstract}

Kata kunci: debt ratio, debt to equity ratio, loan to deposit ratio, return on equity

\begin{abstract}
Profitability is an appropriate indicator to measure the performance of a bank. profitability assessment useful to determine the ability of companies in creating profit from capital used. This study aims to determine the effect of Capital Structure and Liquidity to Profitability of Bank Companies in Indonesia Stock Exchange. The population used in this study are all banking companies listed on the Indonesia Stock Exchange period 2013-2016. Sampling technique used is purposive sampling, based on sample determination criteria then the samples obtained are 33 banking companies listed on the Indonesia Stock Exchange period 2013-2016. Based on the results of the analysis found that the debt ratio has a negative significant effect to the return on equity of the Bank companies in the Indonesia Stock Exchange, debt to equity ratio have a positive significant effect to the return on equity of the bank companies in Indonesia Stock Exchange, loan to deposit ratio positive significant to return on equity a bank company on the Indonesia Stock Exchange.
\end{abstract}

Keywords: debt ratio, debt to equity ratio, loan to deposit ratio, return on equity 
Kadek Rionita, Pengaruh Struktur Modal dan Likuiditas...]

\section{PENDAHULUAN}

Sektor perbankan memegang peranan yang sangat penting dalam perekonomian suatu negara karena bank merupakan lembaga intermediasi yang menghubungkan antara masyarakat yang memiliki kelebihan dana dan masyarakat yang membutuhkan dana, selain itu bank merupakan penunjang sektor riil yang berperan aktif dalam perekonomian Indonesia. Berdasarkan hal tersebut maka bank dalam kegiatan operasional memiliki tujuan jangka pendek maupun tujuan jangka panjang. Tujuan jangka pendek bank adalah untuk memperoleh laba yang maksimal dan tujuan jangka panjangnya adalah mempertahankan kualitas usahanya.

Perkembangan dunia perbankan dewasa ini sudah semakin meningkat seiring dengan perkembangan teknologi informasi disamping karena meningkatnya kepercayaan masyarakat terhadap perbankan. Berdasarkan hal tersebut untuk menjaga kepercayaan masyarakat terhadap perbankan maka bank dituntut untuk selalu memperbaiki kinerjanya. Memperbaiki kinerja perusahaan salah satunya dengan meningkatkan profitabilitas. Profitabilitas merupakan ukuran kemampuan bank untuk menghasilkan laba dari modal yang dimilikinya atau dapat dikatakan profitabilitas merupakan kemampuan dari bank untuk memperoleh laba dalam hubungannya dengan penjualan, total aktiva maupun modal sendiri. Rasio Return On Equity (ROE) adalah rasio yang digunakan untuk mengukur kemampuan bank dalam memanfaatkan modal sendiri untuk menghasilkan keuntungan (Sudirman,2013). Semakin tinggi ROE menunjukkan semakin efisien bank menggunakan modal sendiri untuk menghasilkan laba atau keuntungan bersih. 
E-Jurnal Manajemen Unud, Vol.-, No. -, 2018 :-

Struktur modal merupakan pendanaan kegiatan bank yang terdiri dari kombinasi utang dan modal sendiri yang digunakan oleh bank. Pendapatan yang diperoleh bank dapat ditingkatkan dengan penggunaan struktur modal yang maksimal. Secara teoritis penggunaan utang akan dapat meningkatkan laba dan selanjutnya dapat meningkatkan profitabilitas jika laba yang diperoleh tersebut melebihi beban bunga hutangnya. Sebaliknya jika laba diperoleh dari penggunaan hutang tersebut lebih kecil dari beban bunga hutang maka laba yang diperoleh bank akan menurun dan profiitabilitasnyapun dapat menurun. Beberapa rasio yang dapat digunakan Bank dalam mengukur struktur modalnya antara lain debt ratio dan debt to equity ratio. Debt Ratio (DR) merupakan rasio utang yang digunakan untuk mengukur seberapa besar asset perusahaan dibiayai oleh utang atau menunjukkan seberapa besar proporsi antara kewajiban dengan kekayaan yang dimiliki. Modal utang yang digunakan bank untuk meningkatkan operasional akan berdampak pada peningkatan laba dari perusahaan sehingga bank dapat membayar pokok pinjaman, angusran dan bunga. Semakin tinggi debt ratio maka semakin besar jumlah modal pinjaman yang digunakan dalam menghasilkan keuntungan (Syamsuddin,2011:54). Pendapat ini didukung oleh penelitian Woldemariam Biru (2016) yang menemukan bahwa DR berpengaruh positif signifikan terhadap return on equity. Penelitian yang dilakukan oleh Zulfadli (2013) menemukan bahwa DR berpengaruh positif signifikan terhadap ROE. Hasil penelitian yang sama juga ditemukan oleh Kurniawati dkk. (2015) bahwa DR berpengaruh positif terhadap ROE. Penelitian yang dilakukan oleh Herdiani dkk. (2013) menemukan hasil yang berbeda bahwa DR berpengaruh negatif terhadap ROE. Debt to Equity Ratio (DER) merupakan 
rasio perbandingan antara total utang dengan total modal dari perusahaan. Utang ini muncul karena tidak semua kebutuhan perusahaan mampu dibiayai oleh modal sendiri atau dengan perolehan dari penjualan saham sehingga perusahaan biasanya akan mencari tambahan modal melalui utang. Bagi perusahaan, semakin besar DER semakin baik karena mampu menghemat pajak (tax shields), apabila DER perusahaan kecil maka pendanaan yang disediakan pemilik sebagai jaminan semakin tinggi dan batas pengamanan pinjaman semakin besar (Kasmir, 2014:158). Rasio ini memberikan gambaran mengenai struktur modal yang dimiliki perusahaan, sehingga dapat diamati tingkat risiko tak tertagihnya suatu utang. Semakin tinggi tingkat utang perusahaan maka semakin tinggi keuntungan yang diperoleh karena mampu menghemat pajak yang harus dibayarkan. Pendapat ini didukung oleh penelitan yang dilakukan oleh Woldemariam Biru (2016) yang menemukan bahwa DER berpengaruh positif signifikan terhadap ROE. Hal ini sejalan dengan penelitian Herdiani dkk. (2013) yang menemukan bahwa DER berpengaruh positif signifikan terhadap ROE. Hasil penelitian yang berbeda ditemukan oleh Andrean (2016) yang menemukan bahwa DER berpengaruh negatif signifikan terhadap ROE.

Likuiditas merupakan rasio yang menggambarkan kemampuan perusahaan memenuhi kewajiban (utang) jangka pendek. Rasio likuiditas yang umum dipergunakan di dalam perbankan adalah Loan to Deposit Ratio (Sudirman, 2013:185). Menurut Peraturan Bank Indonesia No.17/11/PBI/2015, Loan to Deposit Ratio tentang Giro Wajib Minimum Bank Umum dalam rupiah dan valuta 
E-Jurnal Manajemen Unud, Vol.-, No. -, 2018 :-

asing bagi bank umum konvensional beserta peraturan dan pelaksanaannya dibaca sebagai Loan to Funding Ratio atau LFR sejak taggal 3 Agustus 2015. Peraturan Bank Indonesia No.19/6/PBI/2017 menyatakan bahwa LFR merupakan rasio kredit yang diberikan kepada pihak ketiga dalam Rupiah dan valuta asing tidak termasuk kredit kepada bank lain terhadap dana pihak ketiga yang mencakup giro, tabungan, dan deposito dalam rupiah dan valuta asing tidak termasuk dana antar bank dan surat berharga dalam rupiah dan valuta asing yang memenuhi persayaratan tertentu yang diterbitkan oleh bank untuk memperoleh sumber pendanaan. Peraturan Bank Indonesia No. 19/6/PBI/2017 menyatakan bahwa batas bawah Loan to Funding Ratio sebesar $78 \%$ dan batas atas Loan to Funding Ratio sebesar 92\%. Tinggi rendahnya tingakat LDR suatu bank akan mempengaruhi Profitabilitas suatu bank tersebut. Semakin besar jumlah dana yang disalurkan kepada nasabah dalam bentuk kredit maka penghasilan bunga yang diperoleh akan meningkat, hal ini akan membuat profitabilitas meningkat dengan asumsi bank tersebut mampu menyalurkan kredit dengan efektif. Apabila bank mengalami kesulitan dalam meyalurkan dana, hal ini membuat banyak dana mengangur dan menyebabkan tingkat profitabilitas bank menurun karena bank tidak efektif dalam menyalurkan dana.

Sofyan (2016) dalam penelitiannya menemukan bahwa LDR berpengaruh positif signifikan terhadap ROE. Penelitian yang sama juga ditemukan oleh Shofar Naryoto dan Maulidia (2015) menemukan bahwa LDR berpengaruh positif signifikan terhadap ROE. Didukung oleh penelitian Henny 2016 bahwa LDR berpengaruh positif signifikan terhadap ROE. Penelitian yang berbeda ditemukan 
oleh Woldermariam Biru (2016) banhwa LDR tidak berpengaruh terhadap ROE. Constantion Alexious dan Voyazas Sofoklis (2009) dalam penelitian Permatasari (2012) yang menemukan bahwa LDR berpengaruh negatif signifikan terhadap ROE.

Beberapa penelitian mengenai pengaruh struktur modal dan likuiditas terhadap profitabilitas telah dilakukan, salah satunya yang dilakukan oleh Woldemariam Biru (2016) yang meneliti mengenai pengaruh struktur modal terhadap kinerja keuangan bank umum di Ethiopia menemukan bahwa struktur modal yang diukur dengan proksi DR dan DER berpengaruh positif signifikan terhadap profitabilits yang diukur dengan ROE. Sementara likuiditas yang diukur dengan proksi LDR tidak berpengaruh signifikan terhadap profitabilitas yang diukur dengan ROE. Ditemukannya research gap pada penelitian sebelumnya dan pentingnya perbankan bagi perekonomian suatu negara membuat penelitian ini perlu dilakukan serta untuk menambah referensi penelitian mengenai topik ini.

Tujuan dilakukannya penelitian untuk mengetahui pengaruh struktur modal dan likuiditas terhadap profitabilitas bank di Bursa Efek Indonesia. Penelitian ini memeiliki dua maafaat, yaitu manfaat teoritis dan kegunaan praktis. Manfaat teoritis berupa hasil dari penelitian ini dapat memberikan bukti empiris bagi peneliti di masa mendatang mengenai pengaruh struktur modal dan likuiditas terhadap profitabilitas perusahaan bank di Bursa Efek Indonesia Manfaat praktif berupa hasil dari penelitian ini diharapkan berguna bagi perusahaan, manajer keuangan, investor dan pihak-pihak lain sebagai tambahan informasi serta bahan pertimbangan dalam memilih keputusan investasi yang lebih bijaksana. 
E-Jurnal Manajemen Unud, Vol.-, No. -, 2018 :-

Profitabilitas dalam dunia perbankan sangat penting baik untuk pemilik, penyimpan, pemerintah, dan masyarakat. Memperoleh laba yang besar belum menjadi ukuran bahwa perusahaan sudah bekerja secara efisien. Efisien suatu peusahaan dapat diketahui dengan membandingkan laba yang diperoleh tersebut dengan kekayaan atau modal yang menghasilkan laba tersebut. Sehingga hal yang harus diperhatikan adalah bagaimana mendapat titik profitabilitas yang maksimal dibandingkan laba yang maksimal. Indikator yang dapat digunakan untuk mengukur profitabilitas salah satunya adalah Return On Equity (ROE). ROE merupakan indikator untuk mengukur kinerja manajemen bank dalam mengelola modal yang tersedia untuk menghasilkan laba setelah pajak. Kemampuan bank dengan menggunakan ROE dalam memperoleh laba tidak diukur menurut besar kecilnya jumlah laba yang dicapai tetapi jumlah laba tersebut harus dibandingkan dengan jumlah dana yang telah digunakan dalam menghasilkan laba tersebut. Semakin tinggi ROE menunjukkan semakin efisien bank menggunakan modal sendiri untuk menghasilkan laba atau keuntungan bersih.

Struktur modal merupakan kombinasi antara utang dan ekuitas yang akan digunakan dalam kegiatan operasional perusahaan (Brigham and Houston,2011:155). Secara teoritis penggunaan utang akan dapat meningkatkan laba yang diperoleh tersebut melebihi beban bunga hutangnya. Beberapa rasio yang dapat digunakan perusahaan untuk mengukur struktur modal yaitu debt ratio dan debt to equity ratio. Debt ratio merupakan rasio utang yang digunakan untuk mengukur perbandingan antara total utang dengan total aktiva. Semakin tinggi debt ratio (DR) semakin besar jumlah modal pinjaman yang digunakan didalam 
menghasilkan keuntungan. Semakin rendah rasio hutang maka semakin bagus perusahaan. Berdasarkan hal tersebut maka sebagian kecil aset perusahaan yang dibiayai dengan hutang (Sartono, 2011:54). Aset tetap yang dibiayai dengan utang perusahaan akan dapat meningkatkan kegiatan operasional perusahaan sehingga perusahaan dapat meningkatkan laba perusahaan. Beban perusahaan menimbulkan angsuran pinjaman beserta bunga, selain itu modal utang yang digunakan perusahaan untuk meningkatkan operasional perusahaan meningkatnya laba perusahaan sehingga memberikan kemudahan untuk perusahaan dalam membayar angsuran bunga. Hal ini didukung dengan Trade off theory yang berasumsi bahwa adanya manfaat pajak akibat penggunaan utang, sehingga perusahaan akan menggunakan utang sampai tingkat tertentu untuk memaksimalkan nilai perusahaan (Brigham dan Houston, 2011). Penelitian yang dilakukan oleh Woldemariam Biru (2016) di Ethiopia, menemukan bahwa DR berpengaruh positif signifikan terhadap ROE. Penelitian yang sama juga ditemukan oleh Henny Yulstiati (2016) menunjukkan bahwa DR berpengaruh positif terhadap ROE. Berdasarkan pemikiran tersebut hipotesis yang dapat diajukan dalam penelitian ini adalah:

$\mathrm{H}_{1}$ : Debt Ratio berpengaruh positif signifikan terhadap Return On Equity

Utang muncul karena tidak semua kebutuhan perusahaan mampu dipenuhi oleh modal sendiri sehingga perusahaan mencari tambahan modal melalui utang. Debt to Equity Ratio (DER) yaitu perbandingan antara total utang dan total equitas yang dimiliki perusahaan. Berdasarkan hal tersebut sesuai dengan trade off theory yang diungkapkan oleh Myers yang menyatakan bahwa perusahaan 
E-Jurnal Manajemen Unud, Vol.-, No. -, 2018 :-

akan menggunakan utang sampai pada tingkat utang tertentu, dimana penghematan pajak (tax shields) dari tambahan utang sama dengan biaya kesulitan keuangan (financial distress). Besarnya utang dalam struktur modal perusahaan sangat penting untuk memahami perimbangan antara risiko dan laba yang didapat. Utang membawa risiko karena setiap utang pada umumnya akan menimbulkan keterikatan yang tetap bagi perusahaan berupa kewajiban untuk membayar beban bunga beserta cicilan kewajiban pokoknya. Zulfadli (2013) dalam penelitiannya menemukan bahwa DER berpengaruh positif terhadap ROE. Hal yang sejalan juga dikemukakan oleh Salim (2015) menunjukkan bahwa DER berpengaruh positif signifikan terhadap ROE. Penelitian yang sama juga dilakukan oleh Woldemariam Biru, Mathewos (2016) menemukan bahwa DER berpengaruh positif terhadap ROE. Berdasarkan pemikiran tersebut, hipotesis yang dapat diajukan dalam penelitian ini adalah:

$\mathrm{H}_{2}$ : Debt to Equity Ratio berpengaruh positif signifikan terhadap Return On Equity Likuiditas adalah rasio yang menggambarkan kemampuan perusahaan memenuhi kewajiban (utang) jangka pendek (Fred Weston dalam Kasmir 2012:129). Pengelolaan likuiditas merupakan masalah yang cukup kompleks dalam kegiatan operasional bank, hal tersebut dikarenakan dana yang dikelola oleh bank sebagian besar adalah dana dari masyarakat yang bersifat jangka pendek dan dapat ditarik sewaktu-waktu (Puspitasari, 2009). Kemampuan bank dalam mengelola likuiditasnya akan berdampak terhadap kepercayaan masyarakat kepada bank itu sendiri sehingga akan membantu kelangsungan operasional maupun keberadaan bank tersebut. Rasio likuiditas yang umum dipergunakan di dalam perbankan 
adalah Loan to Deposit Ratio (Sudirman, 2013:185). Menurut Peraturan Bank Indonesia No.17/11/PBI/2015, Loan to Deposit Ratio tentang Giro Wajib Minimum Bank Umum dalam rupiah dan valuta asing bagi bank umum konvensional beserta peraturan dan pelaksanaannya dibaca sebagai Loan to Funding Ratio atau LFR sejak taggal 3 Agustus 2015. Peraturan Bank Indonesia No.19/6/PBI/2017 menyatakan bahwa LFR merupakan rasio kredit yang diberikan kepada pihak ketiga dalam Rupiah dan valuta asing, tidak termasuk kredit kepada bank lain terhadap dana pihak ketiga yang mencakup giro, tabungan, dan deposito dalam rupiah dan valuta asing tidak termasuk dana antar bank dan surat berharga dalam rupiah dan valuta asing yang memenuhi persayaratan tertentu yang diterbitkan oleh bank untuk memperoleh sumber pendanaan. LDR atau LFR yang tinggi dalam suatu bank akan menunjukkan profitabilitas yang besar, karena kredit yang disalurkan oleh bank dijalankan dengan efektif. Berdasarkan penelitian yang dilakukan Sofyan (2016) menunjukkan bahwa LDR berpengaruh positif terhadap ROE. Penelitian yang sama juga ditemukan oleh Ali (2015) bahwa LDR berpengaruh positif signifikan terhadap ROE. Hal ini juga didukung oleh Maulida (2016) menunjukkan bahwa LDR berpengaruh positif signifikan terhadap ROE. Berdasarkan pemikiran tersebut, hipotesis yang dapat diajukan dalam penelitian ini adalah:

$\mathrm{H}_{3} \quad$ : Loan to Deposit Ratio berpengaruh positif signifikan Return On Equity

\section{METODE PENELITIAN}

Penelitian ini menggunakan pendekatan kuantitatif dengan bentuk asosiatif untuk dapat mengetahui pengaruh struktur modal dan likuiditas terhadap 
E-Jurnal Manajemen Unud, Vol.-, No. -, 2018 :-

profitabilitas perusahaan bank di Bursa Efek Indonesia. Penelitian dilakukan pada seluruh perusahaan-perusahaan perbankan yang terdaftar di Bursa Efek Indonesia (BEI) dapat diakses dengan alamat website $\underline{w w w . i d x}$.co.id. Objek penelitian ini adalah perusahaan-perusahaan perbankan yang terdaftar di Bursa Efek Indonesia pada tahun 2013-2016. Variabel penelitian ini berjumlah 4 variabel, 1 variabel terikan dan 3 variabel bebas. Variabel dependent atau variabel terikat dalam penelitian ini adalah return on equity. Variabel independen atau variabel bebas dalam penelitian ini adalah debt ratio $\left(\mathrm{X}_{1}\right)$, debt to equity ratio $\left(\mathrm{X}_{2}\right)$, loan to deposit ratio $\left(\mathrm{X}_{3}\right)$. Persamaan regresi linier berganda dapat dirumuskan sebagai berikut:

$$
\mathrm{Y}=\mathrm{a}+\mathrm{b}_{1} \mathrm{x}_{1}+\mathrm{b}_{2} \mathrm{X}_{2}+\mathrm{b}_{3} \mathrm{X}_{3}+\mathrm{e}
$$

Keterangan :

$\mathrm{Y} \quad=$ Profitabilitas

$\mathrm{X} 1=$ Debt Ratio

$\mathrm{X} 2=$ Debt to Equity Ratio

$\mathrm{X} 3=$ Loan to Deposit Ratio

$\mathrm{a} \quad=$ Konstanta

$\mathrm{b}_{1}=\mathrm{b}_{2}=\mathrm{b}_{3}=$ arah garis regresi yang menyatakan perubahan nilai $\mathrm{Y}$ akibat perubahan 1 unit X (koefisien regresi masing-masing X1)

e = Variabel Penggangu.

Profitabilitas yang diukur dengan proksi return on equity merupakan perbandingan antara laba bersih setelah pajak dengan modal sendiri dikali 100 
persen di perusahaan-perusahaan perbankan yang terdaftar di Bursa Efek Indonesia tahun 2013-2016 dapat dirumus sebagai berikut :

$\mathrm{ROE}=\frac{E A T}{\text { Modal }} \times 100 \%$

Struktur modal yang diukur dengan proksi debt ratio dan debt to equity rati. Debt rasio merupakan perbandingan antara total utang dengan total aktiva dikali 100 persen, di perusahaan-perusahaan perbankan yang terdaftar di Bursa Eefek Indonesia tahun 2013-2016 dapat dirumuskan sebagai berikut:

$\mathrm{DR}=\frac{\text { Total Debt }}{\text { Total Assets }} \times 100 \%$

Debt to equity ratio merupakan perbandingan antara total utang dengan total modal dikali 100 persen, di perusahaan-perusahaan perbankan yang terdaftar di Bursa Efek Indonesia tahun 2013-2016 dapat dirumuskan sebagai berkut:

$\mathrm{DER}=\frac{\text { Total Debt }}{\text { Total Equitas }} \times 100 \%$

Likuiditas yang diukur dengan proksi loan to deposit ratio. Loan to deposit ratio merupakan perbandingan antara total kredit dengan total dana pihak ketiga dikali 100 persen, di perusahaan-perusahaan perbankan yang terdaftar di Bursa Efek Indonesia tahun 2013-2016 dapat diukur sebagai berkut:

$\mathrm{LDR}=\frac{\text { Total Kredit }}{\text { Total Dana Pihak Ketiga }} \times 100 \%$

Penelitian ini menggunakan populasi pada perusahaan-perusahan perbankan berjumlah 43 yang terdaftar BEI pada tahun 2013-2016. Teknik penentu sampel yang digunakan dalam penelitian ini menggunakan teknik secara purpose sampling. Metode purpose sampling adalah pengambilan sampel yang bertujuan mengambil sampel populasi berdasarkan suatu kriteria tertentu. Sampel yang 
E-Jurnal Manajemen Unud, Vol.-, No. -, 2018 :-

dipilih dalam penelitian ini memenuhi kriteria, bahwa bank yang memiliki laba positif selama tahun pengamatan yaitu 2013 sampai 2016 dan perusahaan bank, secara terus-menerus mempublikasi laporan keuangan tahunan selama empat tahun berturut-turut yakni tahun 2013, 2014, 2015, 2016. Berdasarkan kriteria tersebut, dalam penelitian ini diperoleh 31 perusahaan pada sektor perbankan di Bursa Efek Indonesia sebagai sampel penelitian. Metode pengumpulan data dalam penelitian ini menggunkan metode observasi nonpartisipan, yaitu metode teknik pengumpulan data dengan melakukan pencatatan terhadap data-data yang diperoleh perusahaan pada perusahaan bank yang terdaftar di BEI dimana peneliti tidak terlibat langsung dalam aktivitas perusahaan dan hanya sebagai pengamat independent. Data-data yang diperlukan berupa laporan keuangan dari perusahaan bank yang diperoleh di www.idx.co.id. Teknik analisi data yang digunakan berupa analisis regresi linier berganda dan uji asumsi klasik. Sebelum model regresi digunakan, perlu dilakukan pengujian asumsi klasik terlebih dahulu yang meliputi Uji Normalitas, Uji Autokorelasi, Uji Multikolieritas, dan Uji Heteroskedastisitas.

\section{PEMBAHASAN}

Analisis statistik deskriptif memberikan gambaran atau deskripsi mengenai data variabel penelitian yang terlihat dari jumlah pengamatan, nilai rata - rata (mean), standar deviasi, nilai minimum, nilai maksimum dan range. Tabel berikut menampilkan statistik deskriptif variabel yang telah diuji dengan menggunakan program bantuan Software Statistical Packages for Social Science (SPSS) for Windows version 23. 
Tabel 1

Statistik Deskriptif Variabel Penelitian

Perusahaan Bank di Bursa Efek Indonesia Periode 2013-2016

\begin{tabular}{lcccccc}
\hline \multicolumn{1}{c}{} & $\mathrm{N}$ & Range & Minimum & Maximum & Mean & Std. Deviation \\
\hline Debt Ratio & 124 & 21 & 74 & 95 & 85.96 & 4.123 \\
Debt to Equity & 124 & 1537 & 284 & 1821 & 695.23 & 252.790 \\
$\begin{array}{l}\text { Ratio } \\
\text { Loan to Deposit }\end{array}$ & 124 & 55.58 & 45.72 & 101.30 & 82.7715 & 11.83017 \\
Ratio & & 83.50 & .29 & 83.79 & 13.6374 & 11.70041 \\
Return On Equity & 124 & & & & & \\
Valid N (listwise) & 124 & & & & & \\
Sumber: Data diolah, 2018 & &
\end{tabular}

Berdasarkan hasil pengujian tersebut menunjukkan bahwa jumlah observasi data yang digunakan dalam penelitian ini berjumlah 124 data yang didapatkan dari 31 sampel laporan keuangan perusahaan bank dikalikan 4 tahun (2013-2016). Berdasarkan analisis statistik deskriptif pada tabel 1 menunjukkan nilai rata-rata (mean) return on equity bernilai positif yaitu sebesar 13,6374 persen, yang memiliki arti bahwa setiap tahunnya selama periode 2013-2016 rata-rata ROE mengalami peningkatan. Standard deviasi sebesar 11,70041. Nilai terendah (minimum) dari Return On Equity (Y) adalah 0,29 persen dimiliki oleh Bank QNB Indonesia TBK, sedangkan nilai tertinggi (maximum) dari Return On Equity (Y) sebesar 83,79 persen dimiliki oleh Bank Pembangunan Daerah Banten. Nilai range sebesar 83,50 persen tersebut menunjukkan selisih antara nilai maksimum dan nilai minimum dari perusahaan perbankan yang terdaftar di BEI selama periode 20132016.

Berdasarkan analisis statistik deskriptif yang ditunjukkan pada tabel 1 menunjukkan nilai rata-rata (mean) dari Debt Ratio 85,96 persen dengan standar deviasi sebesar 4,123. Nilai terendah (minimum) dari Debt Ratio (X1) adalah 74 persen dimiliki oleh Bank Nationalnobu Tbk, sedangkan nilai tertinggi (maximum) 
E-Jurnal Manajemen Unud, Vol.-, No. -, 2018 :-

dari Debt Ratio (X1) sebesar 95 persen dimiliki oleh Bank Pembangunan Daerah Banten. Nilai range sebesar 21 persen tersebut menunjukkan selisih antara nilai maksimum dan nilai minimum dari perusahaan perbankan yang terdaftar di BEI selama periode 2013-2016.

Berdasarkan analisis statistik deskriptif yang ditunjukkan pada tabel 1 menunjukkan nilai rata-rata (mean) dari Debt to Equity Ratio 695,23 persen dengan standar deviasi sebesar 252,790. Nilai terendah (minimum) dari Debt to Equity Ratio (X2) adalah 284 persen dimiliki oleh Bank Nationalnobu Tbk, sedangkan nilai tertinggi (maximum) dari Debt to Equity Ratio (X2) sebesar 1821 persen dimiliki oleh Bank Pembangunan Daerah Banten. Nilai range sebesar 1537 persen tersebut menunjukkan selisih antara nilai maksimum dan nilai minimum dari perusahaan perbankan yang terdaftar di BEI selama periode 2013-2016.

Berdasarkan analisis statistik deskriptif yang ditunjukkan pada tabel 1 menunjukkan nilai rata-rata (mean) dari loan to deposit ratio 82,7715 persen dengan standar deviasi sebesar 11,831017. Nilai terendah (minimum) dari loan to deposit ratio (X3) adalah 55,58 persen dimiliki oleh Bank Nationalnobu Tbk, sedangkan nilai tertinggi (maximum) dari loan to deposit ratio (X3) sebesar 101,30 persen dimiliki oleh Bank Mestika Dharma Tbk. Nilai range sebesar 55,58 persen tersebut menunjukkan selisih antara nilai maksimum dan nilai minimum dari perusahaan perbankan yang terdaftar di BEI selama periode 2013-2016.

Uji normalitas bertujuan untuk mengetahui apakah residuan dari model regresi yang akan diteliti berdistribusi normal atau tidak. Uji normaliitas dapat dilakukan dengan dua cara yaitu dengan analisis grafik dan uji statistik (Ghozali, 
2012:160). Dalam penelitian ini uji normalitas dilakukan dengan menggunakan uji statistik yaitu uji Kolmogorov-Smirnov. Jika nilai koefisien pada Asymp. Sig (2tailed) menunjukkan angka yang lebih besar dari tingkat signifikansi yang digunakan $(0,05)$ maka model yang digunakan berdistribusi normal, sebaliknya jika nilai koefisien pada Asymp. Sig (2-tailed) menunjukkan angka yang lebih kecil dari tingkat signifikansi yang digunakan $(0,05)$ maka model yang digunakan berdistribusi tidak normal. Hasil uji normalitas dapat dilihat pada Tabel 2.

\section{Tabel 2}

Hasil Uji Normalitas PenelitianPerusahaan Bank di Bursa Efek Indonesia Periode 2013-2016

\begin{tabular}{llc}
\hline & & $\begin{array}{c}\text { Unstandardized } \\
\text { Predicted Value }\end{array}$ \\
\hline $\mathrm{N}$ & Mean & 124 \\
Normal Parameters & & 13.1374194 \\
& Std. Deviation & 3.49184247 \\
Most Extreme Differences & Absolute & .063 \\
& Positive & .063 \\
Test Statistic & Negative & -.061 \\
Asymp. Sig. (2-tailed) & .063 \\
a. Test distribution is Normal. & $.200^{\text {c,d }}$ \\
b. Calculated from data. & \\
c. Lilliefors Significance Correction. & \\
d. This is a lower bound of the true significance. & \\
Sumber $:$ data diolah, 2018 & \\
\hline
\end{tabular}

Berdasarkan hasil penelitian tersebut menunjukkan bahwa nilai koefisien Asymp. Sig. (2-tailed) sebesar 0,200 lebih besar dari signifikansi yang digunakan yakni sebesar $0,05(0,200>0,05)$. Hasil tersebut menunjukkan bahwa data yang digunakan dalam penelitian adalah berdistribusi normal.

Uji autokorelasi bertujuan untuk menguji apakah dalam model regresi terdapat korelasi antara kesalahan penganggu pada periode t dengan kesalahan pengganggu pada periode t-1 (sebelumnya). Model regresi yang baik adalah regresi yang bebas dari autokorelasi (Ghozali, 2012:110). Uji autokorelasi dapat dilakukan dengan beberapa metode, dalam penelitian ini uji autokorelasi dilakukan dengan 
E-Jurnal Manajemen Unud, Vol.-, No. -, 2018 :-

menggunakan metode Uji Durbin - Waston (DW Test). Hasil uji autokorelasi dapat dilihat sebagai Tabel 3.

Tabel 3

Hasil Uji Autokorelasi Penelitian Perusahaan

Bank di Bursa Efek Indoneisa periode 2013-2016

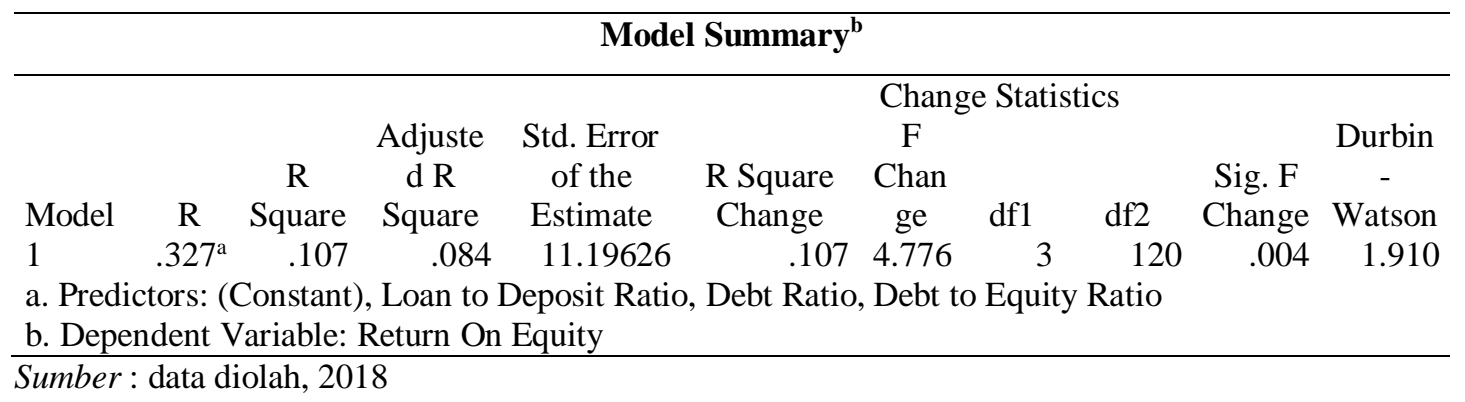

Berdasarkan hasil penelitian tersebut menunjukkan bahwa nilai Durbin - Waston (DW) sebesar 1,910. Berdasarkan tabel DW dengan tingkat signfikansi sebesar 0,05 dan jumlah variabel sebanyak $4(\mathrm{k}=4)$ serta jumlah sampel sebanyak $124(n=132)$ maka dapat diketahui nilai $d_{L}$ dan $d_{U}$. Nilai $d_{L}=$ 1,6409 dan $d_{U}=1,7739$ sehingga $4-d_{U}=2,23756$. Oleh karena nilai DW sebesar 1,910 lebih besar dari batas atas $\left(d_{U}\right)$ sebesar 1,7739 dan kurang dari $4-d_{U}$ sebesar 2,23756, maka dapat disimpulkan bahwa dalam model regresi yang digunakan tidak terjadi autokorelasi atau bebas dari autokorelasi.

Uji multikolinearitas dilakukan untuk menguji apakah model regresi yang digunakan, ditemukan adanya korelasi antara variabel bebas (independen). Model regresi yang baik adalah model regresi yang bebas dari gejala multikolonieritas yang artinya tidak terjadi korelasi diantara variable bebas (Ghozali, 2016:103). Uji multikolinearitas dapat dilakukan dengan mengamati pada nilai koefisien tolerance dan variance inflation factor (VIF). Model regresi dikatakan tidak memiliki gejala multikolinearitas jika nilai tolerance lebih besar atau sama dengan 0,10 (tolerance 
$\geq 0,10$ ) dan variance inflation factor (VIF) lebih kecil atau sama dengan 10 (VIF $\geq$ 10). Hasil uji multikolinearitas dapat dilihat pada Tabel 4.

Tabel 4

Hasil Uji Multikolinearitas Penelitian Perusahaan Bank di Bursa Efek Indonesia Periode 2013-2016

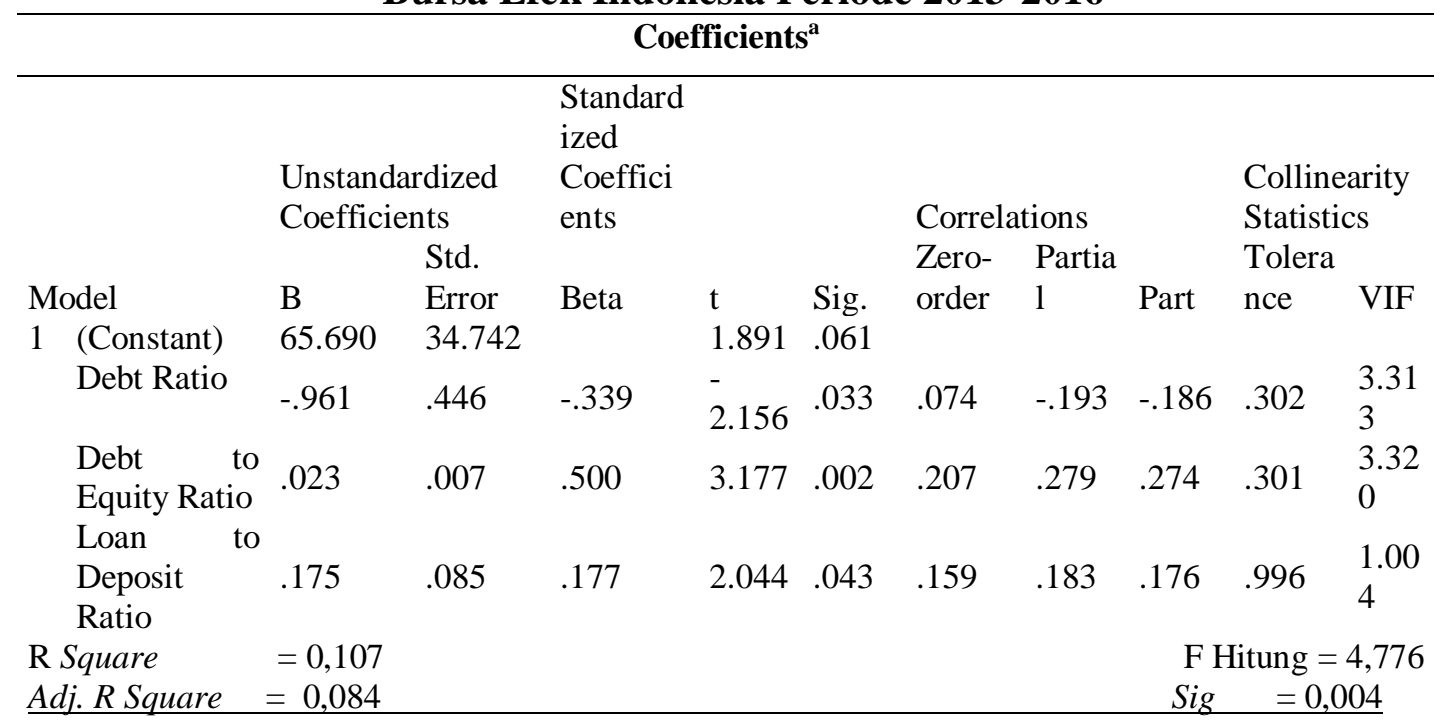

Sumber : data diolah, 2018

Berdasarkan hasil penelitian tersebut menunjukkan bahwa dari setiap variabel yang digunakan yaitu debt ratio (X1), debt to equity ratio (X2), dan loan to deposit (X3), memiliki nilai koefisien tolerance yang lebih besar dari 0,10 dan nilai varian iinflatio factor (VIF) lebih kecil dari 10. Jadi dapat disimpulkan bahwa dalam model regresi yang digunakan tidak terjadi gejala multikoleniaritas antar variabel.

Uji heteroskedastisitas bertujuan untuk menguji apakah dalam model regresi yang digunakan terjadi ketidaksamaan variance dari residual satu pengamatan dengan pengamatan yang lainnya. Model regresi yang baik adalah tidak terjadi heteroskedastisitas (Ghozali, 2012:139). Uji heteroskedastisitas dapat dilakukan dengan beberapa metode, pada penelitian ini uji heteroskedastisitas dilakukan dengan menggunakan uji garis plot yang dimana dilakukan dengan melihat ada 
E-Jurnal Manajemen Unud, Vol.-, No. -, 2018 :-

tidaknya pola tertentu pada grafik scatterplot. Hasil uji heteroskedastisitas dalam penelitian ini dapat dilihat pada Gambar 1.

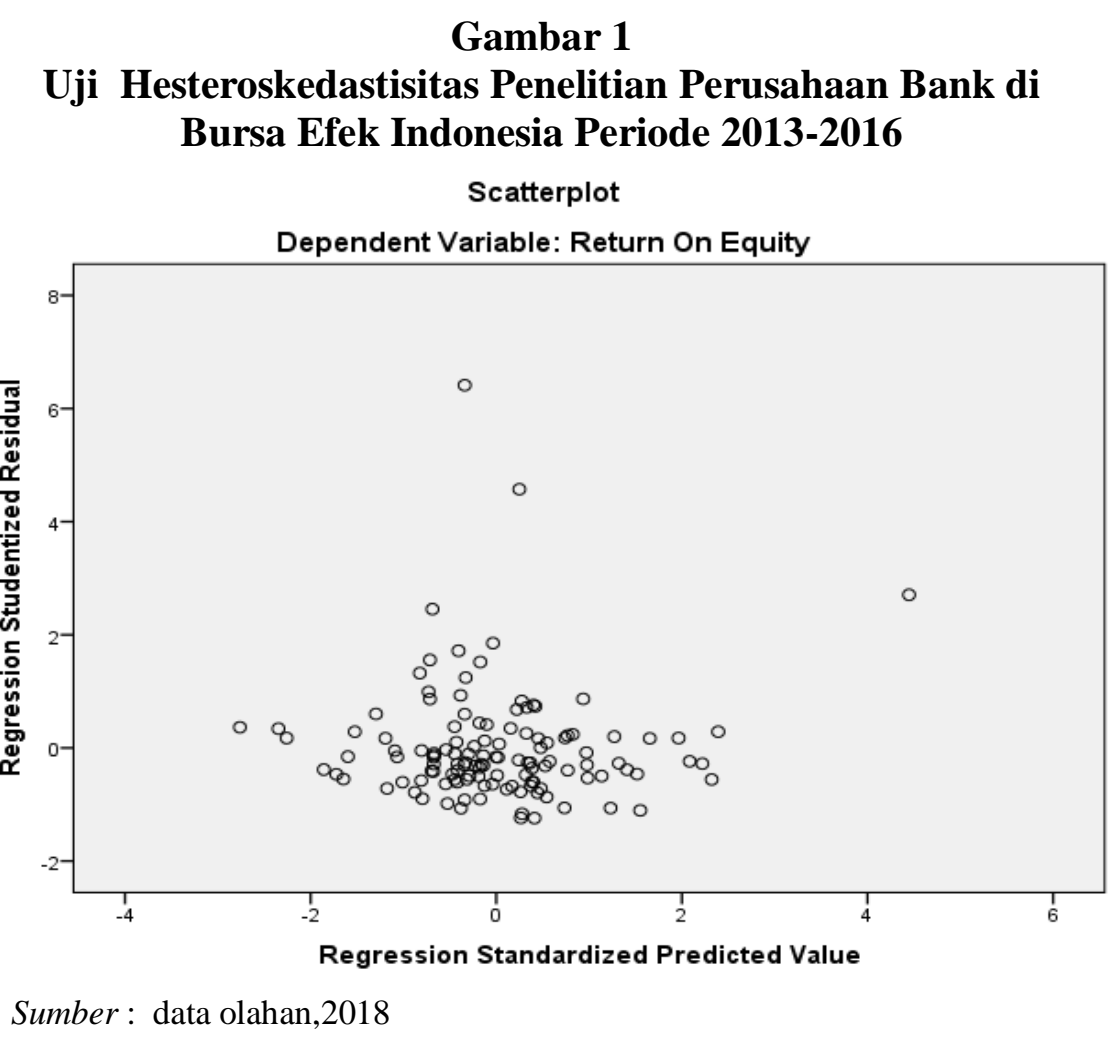

Berdasarkan hasil olahan SPSS pada Gambar 1 menunjukkan bahwa titiktitik menyebar dan tidak membentuk pola tertentu seperti bergelombang, menyebar kemudian menyempit selain itu titik-titik menyebar diatas dan dibawah angka 0 . Sehingga dapat disimpulkan bahwa tidak terjadi masalah heteroskedastisitas.

Analisis linier berganda ini bertujuan untuk mengetahui pengaruh antara variabel bebas yaitu DR (X1), DER (X2), LDR (X3) terhadap variabel terikatnya yaitu ROE (Y) pada perusahaan bank yang terdaftar di Bursa Efek Indonesia periode 2013-2016. Berdasarkan Tabel 4 maka persamaan regresi dari hasil tersebut sebagai berikut:

$Y=65,690-0,961 X 1+0,203 X 2+0,175 X 3$ 
Keterangan :

$$
\begin{array}{ll}
\mathrm{Y} & =\text { Return on Equity }(\mathrm{ROE}) \\
\mathrm{X} 1 & =\text { Debt Ratio }(\mathrm{DR}) \\
\mathrm{X} 2 & =\text { Debt to Equity Ratio }(\mathrm{DER}) \\
\mathrm{X} 3 & =\text { Loan to Deposit Ratio }(\mathrm{LDR})
\end{array}
$$

Persamaan regresi tersebut dapat diuraikan bahwa Nilai koefisien $\beta 1$ sebesar 0,961 berarti, jika nilai variabel DR meningkat sebesar satu persen maka ROE perusahaan Bank menurun sebesar 0,961\% dengan asumsi variabel DER, dan LDR tetap konstan.

Nilai koefisien $\beta 2$ sebesar 0,023 berarti, jika DER meningkat sebesar satu persen maka ROE perusahaan Bank akan meningkat sebesar 0,023\% dengan asumsi variabel DR dan LDR tetap konstan.

Nilai koefisien $\beta 3$ sebesar 0,175 berarti, jika LDR meningkat sebesar satu persen maka ROE perusahaan Bank akan meningkat sebesar 0,175 dengan asumsi variabel DR dan DER tetap konstan.

Koefisien determinasi mengukur sejauh mana kemampuan model regresi dalam menerangkan variasi variabel terikat (Ghozali, 2012:97). Berdasarkan Tabel 4 menunjukkan bahwa nilai $\mathrm{R}$ Square sebesar 0,107. Nilai tersebut mengindikasikan bahwa sebesar 10,7 persen (\%) variabel DR, DER dan LDR, mempengaruhi ROE, sedangkan sisanya sebesar 89,3 persen (\%) dipengaruhi oleh variabel lain yang tidak dimasukkan dalam penelitian ini. 
Tabel 5.

Ringkasan Hasil Uji t

\begin{tabular}{llcc}
\hline No. & Variabel & Koefisien Regresi & Sig. \\
\hline 1. & Debt Ratio & $-0,961$ & 0,033 \\
2. & Debt to Equity Ratio & 0,023 & 0,002 \\
3. & Loan to Deposit Ratio & 0,175 & 0,043 \\
\hline
\end{tabular}

Sumber: data diolah, 2018

Tabel 5 menunjukkan bahwa nilai sig. 0,033 . Nilai sig. $0,033<a=0,05$ hal ini menunjukkan penolakan $\mathrm{H} 0$ yang berarti bahwa secara signifikan debt ratio berpengaruh terhadap return on equity. Koefisien regresi debt ratio X1) sebesar 0,961 menunjukkan adanya pengaruh negatif antara debt ratio terhadap return on equity. Hasil tersebut mengindikaskan bahwa hipotesis 1 yang menyatakan bahwa debt ratio berpengaruh positif signifikan terhadap return on equity tidak sepenuhnya diterima. Dalam penelitian ini debt ratio memiliki pengaruh negatif signifikan terhadap return on equity. Koefisien regresi debt ratio yang negatif pada hasil penelitian ini menunjukkan bahwa semakin tinggi tingkat debt ratio yang digunakan akan semakin tinggi (probabilitas) kebangkrutan dari perusahaan. Ketika jumlah modal pinjaman perusahaan tinggi maka beban bunga yang harus dibayar perusahaan semaki besar sehingga terjadinya penurunan profitabilitas (return on equity) pada perusahaan perbankan yang terdaftar di Bursa Efek Indonesia periode 2013 - 2016.

Hasil penelitian ini sesuai dengan packing order theory yang diungkapkan oleh Myers dimana perusahaan dengan tingkat profitabilitas yang tinggi memiliki tingkat hutangnya rendah, dikarenakan perusahaan yang profitabilitasnya tinggi memiliki sumber dana internal yang berlimpah. Penelitian ini sejalan dengan penelitian yang di lakukan oleh Herdiani dkk (2013) yang menemukan bahwa 
debt ratio berpengaruh negatif signifikan terhadap Return On Equity.

Tabel 5 menunjukkan bahwa nilai sig. 0,002 . Nilai sig. $0,002<a=0,05$ hal ini menunjukkan penolakan $\mathrm{H} 0$ yang berarti bahwa secara signifikan debt to equiy ratio berpengaruh terhadap return on equity. Koefisien regresi debt to equity ratio (X2) sebesar 0,023 menunjukkan adanya pengaruh positif antara debt to equiy ratio terhadap return on equity. Hasil tersebut mengindikaskan bahwa hipotesis 2 yang menyatakan bahwa debt to equiy ratio berpengaruh positif signifikan terhadap return on equity diterima. Dalam penelitian ini debt to equiy ratio memiliki pengaruh positif signifikan terhadap return on equity. Pada hasil penelitian ini debt to equity ratio yang positif menunjukkan bahwa semakin tinggi tingkat struktur modal yang digunakan akan menyebabkan terjadinya peningkatan profitabilitas pada perusahaan perbankan yang terdaftar di Bursa Efek Indonesia periode 2013 - 2016.

Hasil penelitian ini sesuai dengan trade off theory yang diungkapkan oleh Myers yang menyatakan bahwa perusahaan akan menggunakan utang sampai pada tingkat utang tertentu, dimana penghematan pajak (tax shields) dari tambahan utang sama dengan biaya kesulitan keuangan (financial distress) (Dewi dan Wirajaya, 2013). Penelitian ini sejalan dengan Woldemariam Biru, Mathewos (2016) yang menemukan bahwa DER berpengaruh positif terhadap ROE. Hasil penelitian ini juga didukung oleh Salim (2015), Zulfadli (2013) yang menemukan bahwa DER berpengaruh positif signifikan terhadap ROE.

Tabel 5 menunjukkan bahwa nilai sig. 0,043. Nilai sig. 0,043 $<a=0,05$ hal ini menunjukkan penolakan $\mathrm{H} 0$ yang berarti bahwa secara signifikan loan to 
E-Jurnal Manajemen Unud, Vol.-, No. -, 2018 :-

deposit ratio berpengaruh terhadap return on equity. Koefisien regresi loan to deposit ratio (X3) sebesar 0,175 menunjukkan adanya pengaruh positif antara loan to deposit ratio terhadap return on equity. Hasil tersebut mengindikaskan bahwa hipotesis 3 yang menyatakan bahwa loan to deposit ratio berpengaruh positif signifikan terhadap return on equity diterima. Dalam penelitian ini loan to deposit ratio memiliki pengaruh positif signifikan terhadap return on equity. Koefisien loan to deposit ratio yang positif pada hasil penelitian ini menunjukkan bahwa semakin tinggi tingkat LDR maka semakin tinggi dana yang disalurkan ke dana pihak ketiga. Dengan penyaluran dana pihak ketiga yang besar sejalan dengan peningkatan profitabilitas (ROE) karena kredit yang disalurkan oleh bank dijalankan dengan efektif pada perusahaan perbankan yang terdaftar di Bursa Efek Indonesia periode $2013-2016$.

Hasil penelitian ini sesuai dengan teori, dimana semakin tinggi LDR dana yang disalurkan ke dana pihak ketiga maka semakin efektif bank dalam memperoleh laba. Sebaliknya semakin rendah LDR menunjukkan kurangnya efektifitas bank dalam menyalurkan kredit sehingga hilangnya kesempatan bank untuk memperoleh laba. Penelitian ini sejalan dengan peneliti Sofyan (2016) dalam penelitiannya menemukan bahwa LDR berpengaruh positif terhadap ROE. Hasil penelitian ini juga didukung oleh Ali (2015) yang menemukan bahwa LDR berpengaruh positif signifikan terhadap ROE.

Struktur modal merupakan pilihan yang berbeda mengenai keputusan pendanaan perusahaan apakah membiayai operasional perusahaan dengan penggunaan utang ataupun modal sendiri. Hasil penelitian ini menunjukkan 
bahwa struktur modal yang diukur dengan proksi Debt Ratio memiliki pengaruh negatif signifikan terhadap profitabilitas yang diukur dengan proksi Return On Equity. Sedangkan struktur modal yang diukur dengan proksi Debt to Equity Ratio berpengaruh posistif signifikan terhadap profitabilitas yang diukur dengan proksi Return On Equity. Hal ini mengindikasikan implikasi bahwa pentingnya pihak manajemen perusahaan kedepannya untuk memilih struktur modalnya yang paling menguntungkan sehingga dapat meningkatkan profitabilitas perusahaan.

Likuiditas dalam penelitian ini diukur dengan proksi Loan To Deposit Rasio $(L D R)$ merupakan rasio yang digunakan bank dalam membagi jumlah kredit yang diberikan oleh bank terhadap dana pihak ketiga. LDR yang baik bagi suatu bank sesuai dengan peraturan Bank Indonesia No. 19/6/PBI/2017 adalah LDR yang berada antara $78 \%$ sampai $92 \%$. Pada penelitian ini nilai rata-rata LDR bank adalah sebesar $82,7715 \%$ hal ini menunjukkan LDR berada diantara batas bawah dan batas atas LDR yang ditetapkan sehingga bank dalam penelitian ini dikatak baik dalam penyaluran kreditnya.

\section{SIMPULAN DAN SARAN}

Struktur modal yang diukur dengan debt ratio berpengaruh negatif signifikan terhadap profitabilitas yang diukur dengan return on equity pada perusahaan perbankan yang terdaftar di Bursa Efek Indonesia periode 2013 - 2016. Struktur modal yang diukur dengan debt to equity ratio berpengaruh positif signifikan terhadap profitabilitas yang diukur dengan return on equity pada perusahaan perbankan yang terdaftar di Bursa Efek Indonesia periode 2013 - 2016.Likuiditas yang diukur dengan loan to deposit ratio berpengaruh positif signifikan terhadap 
E-Jurnal Manajemen Unud, Vol.-, No. -, 2018 :-

profitabilitas yang diukur dengan return on equity pada perusahaan perbankan yang terdaftar di Bursa Efek Indonesia periode 2013-2016.

Manajemen bank hendaknya memperhatikan proporsi penggunaan utang agar tidak melampaui batas kemampuan perusahaan sehingga penghematan pajak atas utang dapat bermanfaat bagi perusahaan yang nantinya dapat meningkatkan profitabilitas bank. Ketika penambahan aset yang diperoleh dari utang melampaui kemampuan perusahaan hal ini dapat menyebabkan terjadinya penurunan profitabilitas perusahaan, sehingga perusahaan perlu memperhatikan proporsi penggunaan utangnya dan memanfaatkan aset yang dimiliki sebaik mungkin.

Pada penelitian selanjutnya hendaknya mempertimbangkan beberapa variabel lain agar tidak hanya memakai variabel struktur modal proksi debt ratio dan debt to equity ratio serta likuiditas proksi loan to deposit ratio untuk menilai profitabilitas proksi return on equity. Hal ini dikarenakan masih ada faktor lain yang dapat mempengaruhi profitabilitas proksi return on equity. Variable bebas yang digunakan pada penelitian ini berpengaruh sebesar 10,7\% terhadap return on equity dan $89,3 \%$ dipengaruhi oleh faktor lain. Selain itu peneliti selanjutnya hendaknya menambah tahun pengamatan sehingga hasil yang diperoleh dapat digunakan dasar pengambilan keputusan bagi pihak yang bersangkutan.

\section{REFERENSI}

Ali, Shofar Akbar. 2015. Analisis Pengaruh Loan to Deposit Ratio (LDR) dan Debt to Equity Ratio (DER) Terhadap Kinerja Keuangan Return On Equity (ROE) Perusahaan Perbankan Di Indonesia Tahun 2009-2013. Jurnal Manajemen Universitas Muhammadiyah Surakarta.

Astita, Rima. 2013. Pengaruh Likuiditas dan Struktur Modal Terhadap Profitabilitas (Studi Kasus Pada Perusahaan Manufaktur Sektor Food and 
Kadek Rionita, Pengaruh Struktur Modal dan Likuiditas...]

Beverage Yang Terdaftar Di Bursa Efek Indonesia Periode 2007-2012), Jurnal Manajemen Universitas Komputer Indonesia.

Aufan, Dahlan. 2007. Manajemen Bank Umum. Jakatra: Intermedia.

Bank Indonesia. 2015. Peraturan Bank Indonesia Nomor: 17/11 tentang Giro Wajib Minimum. Jakarta: Bank Indonesia.

Bank Indonesia. 2017. Peraturan Bank Indonesia Nomor: 19/16/PBI/2017 tentang Pengertian LFR. Jakarta: Bank Indonesia.

Brigham, E. F. dan J.F Houston. 2011. Manajemen Keuangan. Edisi Sebelas. Jakarta: Salemba Empat.

Bukit, R. B. 2012. Pengaruh Struktur Modal Terhadap Nilai Perusahaan Melalui Profitabilitas: Analisis Data Panel Perusahaan Manufaktur di Bursa Efek Indonesia. Jurnal Keuangan dan Bisnis, 4 (3):205-218.

Bursa Efek Indonesia. 2017. IDX Yearly Statistics 2016. http://www.idx.co.id/. (Diunduh tanggal 18 Agustus 2017).

Dani Permatasari, Anindita. 2012. Analisis Pengaruh CAR, LDR, NIM, NPL, BOPO, GWM, dan Institutional Ownership Terhadap Profitabilitas. Jurnal Manajemen Fakultas Ekonomi dan Bisnis, Universitas Diponegoro.

Dewi, Ayu Sri Mahatma dan Ary Wirajaya. 2013. Pengrauh Struktur Modal, Profitabilitas dan Ukuran Perusahaan pada Nilai Perusahaan. E-Jurnal Akuntansi Universitas Udayana, 4 (2):358-372.

Fahmi, Irham. 2016. Pengantar Manajemen Keuangan. Bandung: Alfabeta.

Gozhali, Imam. 2016. Aplikasi Analisis Multivariate dengan Program IBM SPSS 22. Edisi Delapan. Semarang: Universitas Diponogoro.

Herdiani, T., Darminto dan Endang. 2013. Pengaruh Financial Leverage terhadap Profitabilitas: Studi ada Perusahaan Manufaktur yang Terdaftar di Bursa Efek Indonesia Periode 2009-2011. Jurnal Administrasi Bisnis, 5 (1):1-8.

Hestinoviana, Suhadak and Handayani S.R. 2013. The Influence of Profitability, Solvability, Aset Growth, and Sales Growth Tooward Firm Value. Jurnal Administrasi Bisnis, 4 (1):1-7.

Horne, James C. Van dan John M. Wachowicz. 2012. Prinsip-Prinsip Manajemen Keuangan. Edisi 13. Jakarta: Salemba Empat.

Jannati, I. D., Saifi, M., \& Endang. 2014. Pengaruh Rasio Leverage terhadap Profitabilitas (Studi pada Perusahaan Makanan dan Minuman yang 
Terdaftar di BEI Periode Tahun 2009-2011). Jurnal Administrasi Bisnis, 8 (2): $1-8$.

Kasmir. 2014. Analisis Laporan Keuangan. Edisi 1. Cetakan Keenam. Jakarta: Rajawali Pers.

Khalaf Al Taani. 2013. Capital Structure Effects on Banking Performance: A Case Study of Jordan. International Journal of Economics, Finance and Management Sciences, 1(5): 233-277.

Khan, A. G. 2012. The Relationship of Capital Structure Decisions with Firm Performance: A Study of the Engineering Sector of Pakistan International. Journal of Accounting and Financial Reporting, 2(1): 2162-3082.

Kurniawati, D., Nuzula, N. F., \& Endang. 2015. Pengaruh Financial Leverage terhadap Profitabilitas (Studi pada Perusahaan Industri Kimia yang Listing di BEI Periode 2009-2013). Jurnal Administrasi Bisnis, 1 (1):1-9.

Margetha, Farah. 2011. Manajemen Keuangan Untuk Manajer Nonkeuangan. Penerbit Erlangga.

Maulida Khoirunnisa, Hani. 2016. Pengaruh Capital Adequacy Ratio (CAR), Loan to Deposite Ratio (LDR) dan BOPO terhadap Profitabilitas (ROA dan ROE) Bank Persero Indonesia yang Dipublikasi Bank Indonesia Periode 20122015. 5 (4):1-8.

Michael Holiwono, Andreas. 2016. Pengaruh Struktur Modal terhadap Kinerja Keuangan Perusahaan Sektor Manufaktur Subsektor Makanan dan Minuman yang Terdafatar di BEI (Periode 2010-2014). Jurnal Manajemen Universitas Hasanudin. Makasar.

Muljono, Teguh Pudjo. 1999. Aplikasi Akuntansi Manajemen dalam Praktik Perbankan. Edisi 3. Yogyakarta: BPFE.

Permatasari, Anindita Dani. 2012. Analisis Pengaruh CAR, LDR, NIM, NPL, BOPO, GWM, dan Institutional Ownersihip terhadap Profitabilitas. (Studi Kasus Pada Bank Umum Konvensional Go Publik di Indonesia Periode 2009-2011). Jurnal Manajemen Universitas Diponegoro Semarang.

Pitaloka, Nina Diah. 2009. Pengaruh Faktor-Faktor Intern Perusahaan terhadap Kebijakan Utang: dengan Pendekatan Packing Order Theory. Jurnal Manajemen Universitas Lampung.

Prastiyaningtyas, Fitriani. 2010. Analisis Faktor-Faktor yang Mempengaruhi Profitabilitas Perbankan (Studi pada Bank Umum Go Public yang Listed di Bursa Efek Indonesia Tahun 2005-2008). Jurnal Manajemen Universitas Diponogoro Semarang. 
Kadek Rionita, Pengaruh Struktur Modal dan Likuiditas...]

Prihadi, 2011. Analis Laporan Keuangan Teori dan Aplikasi. Jakarta: PPM

Puspitasari, Diana. 2011. Pengaruh Kecukupan Modal, Likuiditas, dan Efisiensi Operasional terhadap Profitabilitas pada PT Bank Muamalat Indonesia, Tbk. Jurnal Manajemen Universitas Islam Negeri Hidayatullah Jakarta.

Rai Prastuti, Kadek. 2016. Pengaruh Struktur Modal, Kebijakn Deviden dan Ukuran Peursahaan terhadap Nilai Perusahaan Manufaktur di Bursa Efek Indonesia. Jurnal Manajemen Unud, 5 (3):2302-8912.

Riyanto, Bambang. 2001. Dasar-Dasar Pembelanjaan Perusahaan. Yogyakarta: BPFE.

Ronoh, Cheruyot. 2015. Effect of Capital Structure on Financial Performance of Listed Commercial Banks in Kenya: A Case Study of Kenya Commercial Bank Limited. The Strategic Journal of Business and Change Management, 2(2): 751-781.

Saeedi, A. and Mahmoodi. 2011. Capital Structure and Firm Performance: Evidence from Iranian Companies. International Research Journal and Economics, 6(5): 156-166.

Saleem, Qasim, and Rehman, Ramiz Ur. 2011. Impact of Liquidity Ratios on Profitability (Case Of Oil and Gas Companies in Pakistan). Interdisciplinary Journal of Research in Business, 1(7): 95-98.

Salim, Jihan. 2015. Pengaruh Leverage (DAR,DER, Dan TIER) terhadap ROE Perusahaan Properti dan Real Estate Yang Terdaftar di Bursa Efek Indonsia Tahun 2010-2014. Perbanas Review, 1 (1):19-34.

Siamat, Dahlan. 2014. Manajemen Lembaga Keuangan. Cetakan Keempat. Jakarta: FE Universitas Indonesia.

Sofyan. 2016. Pengaruh CAR, BOPO, NPL dan FDR terhadap ROE pada Bank Devisa. Jurnal Ilmu dan Riset Manajemen, 5 (5):1-19.

Sudirman, I Wayan. 2013. Manajemen Perbankan Menuju Bankir Konvensional yang Profesional. Edisi Pertama. Jakarta: Kencana Prenada Media Group.

Sugiono. 2012. Metodologi Penelitian Bisnis. Bandung: Alfabeta.

Syamsuddin, Lukman. 2011. Manajemen Keuangan Perusahaan. Jakarta: PT Raja Grafindo Persada.

Tjahjono, Rudi Setiadi. 2014. Faktor - Faktor yang Mempengaruhi Kinerja Keuangan pada Perusahaan Manufaktur yang Terdaftar di Bursa Efek Indonesia. Jurnal Bisnis dan Akuntansi, 16 (3): 1-22. 
E-Jurnal Manajemen Unud, Vol.-, No. -, 2018 :-

Vodova, Pavla. 2011. Liquidity of Czech Commercial Bank and Its Determinants. International Journal of Mathematical Models and Methods in Applied Sciences, 5(6): 1060-1067.

Wiagustini, Ni Luh Putu. 2014. Manajemen Keuangan. Denpasar: Udayana Press.

Woldemariam Biru, Mathewos. 2016. The Impact of Capital Structure on Financial Performance of Commercial Banks in Ethiopia. Journal of Management and Business Research, 16(8): 42-52.

Yulstiati, Henny. 2016. Pengaruh Debt To Asset Ratio, Debt To Equity Ratio dan Net Profit Margin Terhadap Return On Equity pada Perusahaan Property dan Real Estate yang Terdaftar di Bursa Efek Indonesia. Jurnal Akuntanika, $2(1): 1-25$. 